\title{
РОЛЬ ФІКСОВАНИХ КОМБІНАЦІЙ ПРЕПАРАТІВ У ЛІКУВАННІ АРТЕРІАЛЬНОЇ ГIПЕРТЕНЗІЇ В ТЕРАПЕВТИЧНОМУ СТАЦІОНАРІ ЗА РЕЗУЛЬТАТАМИ РЕТРОСПЕКТИВНОГО ДОСЛІДЖЕННЯ
}

\author{
Н. В. Віннікова, В. В. Шманько \\ Тернопільська міська комунальна лікарня № 3 \\ ДВНЗ «Тернопільський державний медичний університет \\ імені І. Я. Горбачевського МОЗ Украӥни"
}

\begin{abstract}
У статті на основі ретроспективного фармакоепідеміологічного аналізу оцінено ефективність лікування артеріальної гіпертензії, дано фармакоекономічну оцінку антигіпертензивним лікарським засобам, розроблено шляхи оптимізації антигіпертензивної терапії у хворих в лікарняних закладах охорони здоров'я.

На основі ретроспективної оцінки ефективності антигіпертензивної терапії та даних фармакоекономічного аналізу визначено раціональні комбінації антигіпертензивних засобів, які використовуються в реальній клінічній практиці для лікування.
\end{abstract}

\section{THE ROLE OF FIXED COMBINATIONS OF DRUGS IN THE TREATMENT OF HYPERTENSION IN THE THERAPEUTIC HOSPITAL THE RESULTS OF A RETROSPECTIVE STUDY}

\author{
N. V. Vinnikova, V. V. Shmanko \\ Ternopil City Municipal Hospital number 3 \\ I. Horbachevsky Ternopil State Medical University
}

\begin{abstract}
The article on the basis of retrospective pharmacoepidemic analysis analyzes the efficacy of treatment of arterial hypertension, present the pharmacoeconomic assessment antihypertensive remedies, develops the ways of antihypertensive therapy optimization in patients in medical establishments of public health.

On the basis of retrospective assessment of antihypertensive therapy effectiveness and data of pharmacoeconomic analysis there were determined the proper combinations of antihypertensive remedies that are used in real clinical practice for treatment.
\end{abstract}

Вступ. Артеріальна гіпертензія (АГ) належить до важливих медико-соціальних проблем. Це зумовлено ії значним поширенням і постійним зростанням захворюваності. Відомо, що на сьогодні поширеність АГ (за даними ВООЗ) складає 30-45 \% від загальної кількості населення та сягає 80 \% серед осіб похилого віку. За прогнозами експертів, до 2022 року кількість хворих на АГ зросте до 1,5 млрд [3]. В Україні зареєстровано більше 12 млн хворих на АГ, тобто близько третини дорослого населення, серед яких 77 \% знали про цю хворобу [2]. АГ $\epsilon$ провідним чинником ризику мозкових інсультів, інфаркту міокарда, хронічної серцевої недостатності та серцево-судинної смертності, причому є фактором, який досить легко виявляється та корегується.

(c) Н. В. Віннікова, В. В. Шманько, 2015
Основна частина. Особливість сучасної еволюції медикаментозного лікування артеріальної гіпертензії полягає у зростанні ролі комбінованих антигіпертензивних схем. Насамперед це зумовлено невдалими спробами довести переваги основних груп засобів зниження артеріального тиску (АТ) та здатністю покращувати довготривалий прогноз виживання хворих в епідеміологічних дослідженнях $[1,5]$. 3 іншого боку, ключовим фактором зменшення ймовірності ускладнень АГ $є$ досягнення цільових рівнів АТ, що, в свою чергу, зумовлює необхідність поєднання антигіпертензивних засобів.

Медикаментозне лікування АГ проводиться за принципом монотерапії або комбінованої терапії. Монотерапія дозволяє досягти цільового АТ лише у частини гіпертензивних пацієнтів, у більшості ж ви- 
падків необхідне застосування комбінованої терапії. Доступно безліч ефективних і безпечних комбінацій лікарських препаратів. У пацієнтів з м'якою АГ, низьким або помірним кардіоваскулярним ризиком можлива ініціація лікування з монотерапії або з комбінації низьких доз двох антигіпертензивних засобів з подальшим збільшенням дози або кількості засобів при необхідності [6].

При АГ 2 і 3 ступенів, а також при високому і дуже високому кардіоваскулярному ризику в пацієнтів 3 м'якою АГ потрібно з самого початку віддавати перевагу комбінації низьких доз 2 антигіпертензивних засобів. У деяких пацієнтів контроль АТ 2 антигіпертензивними засобами не досягається, і потрібна комбінація 3 і більше [1].

Починаючи з 2003 р., комбінована антигіпертензивна терапія визнана в сучасних узгоджених рекомендаціях пріоритетним напрямом лікування АГ $[2,4]$. Так, за даними метааналізу, ефективність комбінованої антигіпертензивної фармакотерапії в 5 разів вища, ніж монотерапії [9]. Отже, постає питання вибору оптимальних поєднань антигіпертензивних засобів, у тому числі - від самого початку медикаментозної терапії [3]. Ряд останніх досліджень дозволив визначити найефективніші комбінації та відмовитися від деяких із них через недостатню ефективність.

До рекомендованих комбінацій антигіпертензивних препаратів належать [8]:

- діуретик + інгібітор АПФ;

- діуретик + блокатор рецепторів ангіотензину-ІІ;

- бета-адреноблокатор + дигідропирідиновий антагоніст кальцію;

- інгібітор АПФ + антагоніст кальцію;

- блокатор рецепторів ангіотензину-ІІ + антагоніст кальцію.

Тому з метою вивчення застосування фіксованої комбінованої терапії у хворих на АГ проведено ретроспективний фармакоепідеміологічний аналіз антигіпертензивної терапії пацієнтів, які перебували на стаціонарному лікуванні у терапевтичному відділенні міської комунальної лікарні № 3 м. Тернополя за період з січня по грудень 2012 року. Всього було проаналізовано дані 442 медичних карт, серед яких АГ була встановлена у 54,1 \% жінок та у 45,9 \% чоловіків відповідно. Хворих у віковому діапазоні до 50 років виявлено 46 (10,4 \%); 51-60 років - 86 (19,45\%); 61-70 років - 86 (19,45\%); 71-80 років - 159 (36\%); 81 і старші - 65 (14,7 \%). Артеріальна гіпертензія 1 ступеня діагностовано у 63,3 \% пацієнтів, 2 сту- пеня - у 30,7 \% і 3 ступеня - в 6 \%. АГ у обстежених хворих поєднувалась з ішемічною хворобою серця у 79,9 \%, хронічною серцевою недостатністю - у 86,6 \%, порушенням ритму - в 41 \%, ХОЗЛ - у 3,6 \%, ЦД в $12,7 \%, \mathrm{XHH}$ - у $3 \%$.

Фіксовані комбіновані препарати були застосовані у 98 (22,2 \%) пацієнтів, з них найчастіше назначався Діокор (АРА+діуретик) - 50 \%, меншою мірою: Локард (АРА+діуретик) - 16,3 \%, Еналозид (ІАПФ+діуретик) - 11,2 \%, Енеас (ІАПФ+АК) - 7,1 \%, Екватор (ІАПФ+АК) та Ноліпрел (ІАПФ+діуретик) - 3,1 \%, Аккузид (ІАПФ+діуретик), Лізотіазид (ІАПФ+діуретик) та Діфорс (АРА+АК), Сардип (АРА+АК) - 2,05 \%, Ліпразид (ІАПФ+діуретик) - $1 \%$ (рис. 1).

Нині найпоширенішими є фіксовані комбінації ІАПФ або АРА з тіазидовими діуретиками у малих дозах. Переваги такого поєднання:

а) посилення антигіпертензивного ефекту ІАПФ;

б) відсутність несприятливих метаболічних змін, можливих при терапії тіазидовими діуретиками у високих дозах;

в) запобігання «вислизуванню» окремих компонентів нейрогуморальної системи (реніну, ангіотензину-ІІ, альдостерону), характерному для тривалої монотерапії діуретиками або ІАПФ;

г) імовірно, додатковий ефект запобігання судинним ускладненням АГ та зменшення гіпертрофії лівого шлуночка, що потребує перевірки в контрольованих дослідженнях;

д) зменшення вартості лікування порівняно із застосуванням двох препаратів;

е) спрощення режиму приймання препаратів і підвищення прихильності до тривалого лікування АГ.

Загалом діуретики доповнюють і посилюють антигіпертензивну дію інших препаратів «першої лінії». Наслідком застосування діуретиків $є$ підвищення активності ренін-ангіотензинової системи, яке може протидіяти досягненню нормальних рівнів АТ. Додавання ІАПФ або антагоніста рецепторів ангіотензину-ІІ дозволяє послабити цей феномен і підвищити імовірність досягнення бажаного ефекту зниження АТ. I, навпаки, малі дози тіазидових діуретиків «потенціюють» антигіпертензивний ефект ІАПФ, протидіючи формуванню феномену «вислизування» (зокрема, утворенню ангіотензину-ІІ і альдостерону шляхами, незалежними від ангіотензинперетворювального ферменту) і толерантності до лікування. Завдяки зменшенню доз обох препаратів рідше виникають суб'єктивні та метаболічні несприятливі події. 


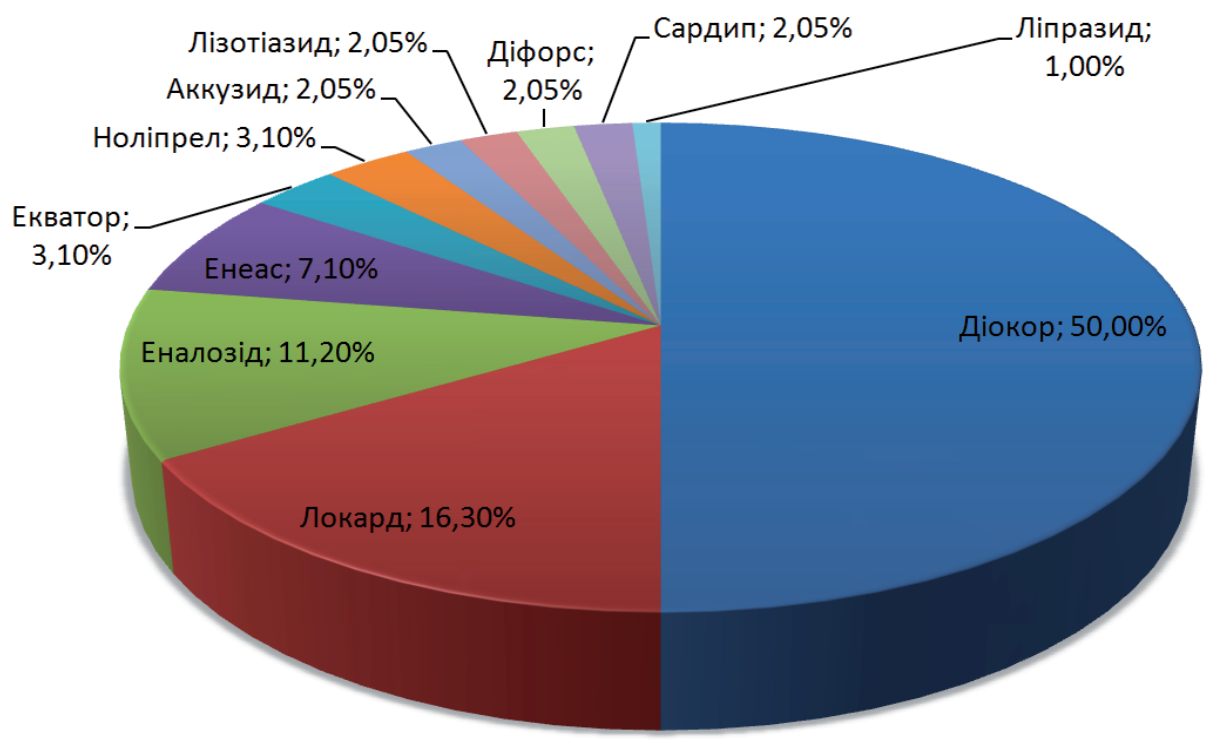

Puc. 1. Частота застосування комбінованих препаратів у хворих на артеріальну гіпертензію в терапевтичному стаціонарі.

Перевагу призначенню комбінацій інгібіторів АПФ/ APA II + діуретик необхідно надавати у пацієнтів із супутньою серцевою недостатністю; супутнім цукровим діабетом; гіпертрофією лівого шлуночка; IXC, в т. ч. перенесеним інфарктом міокарда; атеросклерозом сонних артерій; наявністю мікроальбумінурії; хронічною хворобою нирок (гіпертензивна або діабетична нефропатія) [8].

Найпоширенішими є фіксовані комбінації інгібітору АПФ з дигідропіридинами III покоління, зокрема амлодипіном, нітрендипіном. Як відомо, і інгібітори АПФ і амлодипін з нітрендипіном володіють потужною вазодилатуючою дією, проте механізми, завдяки яким вона реалізується, кардинально відрізняються. Цим зумовлюються потенціювання гіпотензивного впливу та висока ефективність у багатьох пацієнтів як з високореніновою, так і з низькореніновою формами АГ. Поєднане застосування дигідропіридину та інгібітору АПФ дозволяє врівноважити окремі контррегуляторні механізми, зокрема негативний баланс натрію, що викликається амлодипіном, посилює гіпотензивний ефект інгібітору АПФ.

Останній, у свою чергу, пригнічує симпатоадреналову систему, яка хоч і незначною мірою, але все ж зазнає активації при застосуванні амлодипіну [7, 4].

Необхідно зазначити, що інгібітори АПФ та антагоністи кальцію належать до метаболічно нейтральних антигіпертензивних засобів, що робить їх комбінацію цінною для хворих із порушенням ліпідного, вуглеводного та пуринового обміну.

Корекція дози і моніторування АТ можуть здійснюватися з 2-3-місячними інтервалами у пацієнтів із гіпертензією 1 ступеня і в деяких випадках - 2 ступеня. При тяжкій i/або рефрактерній АГ, а також у разі виникнення небажаних ефектів від лікування, контроль можна здійснювати частіше.

Висновки. Перевагами застосування фіксованої комбінації порівняно з монотерапією $є$ простота лікування, що визначає прихильність до терапії та ії ефективність, краща переносимість за рахунок приймання менших доз компонентів комбінації, менша вартість препарату, а також гнучкість, оскільки при збільшенні кількості комбінованих препаратів стають доступними різні режими дозування, що теж розглядається як потенційна перевага.

Комбінована антигіпертензивна терапія на сучасному етапі $\epsilon$ провідним методом лікування АГ більшості хворих, причому часто вона має бути першим кроком лікування. Очевидно, що майбутнє антигіпертензивної терапії - за фіксованими комбінаціями двох і більше препаратів в одній таблетці, що дозволить більш ефективно досягати цільових рівнів АТ як за рахунок потенціювання гіпотензивної дії, так і завдяки збільшенню прихильності хворих до лікування. 


\section{ЛІТЕРАТУРА}

1. Скибчик В. А. Досвід застосування різних схем комбінованої терапії хворих з артеріальною гіпертензією високого і дуже високого ризику / В. А. Скибчик, С. Д. Бабляк // Український медичний часопис. - 2010. - № 6 (80). - С. 94-96.

2. Коваленко В. М. Регіональні особливості рівня здоров'я народу України (аналітико-статистичний посібник) / В. М. Коваленко, В. М. Корнацький. K., 2011. - 165 C.

3. Сіренко Ю. М. Гіпертонічна хвороба і артеріальні гіпертензії : монографія / Ю. М. Сіренко. - Донецьк : Видавець Заславський О. Ю., 2011. - 304 с.

4. Яковлева Л. Н. Комбинированная антигипертензивная терапия: фокус на фиксированную комбинацию эналаприла и нитрендипина / Л. Н. Яковлева // Український кардіологічний журнал. - 2014. № 1. - C. 67-74.

5. Guidelines Committee. 2003 European Society of Hypertension - European Society of Cardiology guidelines for the management of arterial hypertension // J. Hypertension. - 2003. - Vol. 21. - P. 1011-1053.
6. Mancia G., Fagard K., Narkiewicz K. [et al.] 2013 ESH/ESC Guidelines for the management of arterial hypertension: The Task Force for the management of arterial hypertension of the European Society of Hypertension (ESH) and of the European Society of Cardiology (ESC) // European Heart Journal. -doi:10.1093/eurheartj/ eht151.

7. Плєнова О. М. Сучасні підходи до лікування артеріальної гіпертензії - від комбінації окремих препаратів до фіксованих комбінацій / О. М. Плєнова // Внутренняя медицина. - 2007. - Т. 2, № 2. - С. 15-17.

8. Рекомендації Української асоціації кардіологів 3 профілактики та лікування артеріальної гіпертензії : посібник до Національної програми профілактики і лікування артеріальної гіпертензії. - 4-те вид. - К. : ПП ВМБ, 2008. - 80 с.

9. Combination Therapy Versus Monotherapy in Reducing Blood Pressure: Meta-analysis on 11,000 Participants from 42 Trials / D. Wald, M. Law, J. Morris [et al.] // Am. J. Med. 2009. - Vol. 122. - P. 290-300. 